\title{
Christen Dalsgaard som grundtvigsk billedkunstner
}

\author{
Af Nina Hobolth
}

\section{Indledning}

På trods af udmærkede biografier om Christen Dalsgaard er det ikke muligt via den gængse kunsthistoriske litteratur at ane en sammenhæng mellem ham og grundtvigianismen, ud over hvad en enkelt udsmykning på en højskole og et par altertavler i valgmenighedskirker lader ane.

Mit kendskab til Christen Dalsgaard var, ligesom vel de fleste andres, hovedsageligt begrænset til hans virke som genremaler. Men væsentlige undtagelser fra hans genremalerier, som motivisk vakte min nysgerrighed, var to »Ansgar-billeder«. Ved læsning af kulturhistorisk litteratur fik jeg bekræftet - en enkelt gang direkte, men ellers indirekte - Christen Dalsgaards nære forhold til grundtvigske kredse.

Nære bånd mellem mennesker, familiesammenhold, venskaber og åndeligt slægtskab spiller en stor rolle for billedkunstens skabelse og opholdssted. Men i datidens kunsthistoriske litteratur er disse forhold omgået med stor diskretion.

Denne artikel vil beskrive nogle af de opgaver, Christen Dalsgaard udførte for første generation af Grundtvigs »disciple«. Dermed belyses forhåbentlig den særstilling, Christen Dalsgaard indtog som pioner for den grundtvigske billedkunst.

\section{Lidt om Christen Dalsgaards liv og levned}

Christen Dalsgaard (1824-1906) er født på Krabbesholm ved Skive. Han var gennem sin opvækst i nær kontakt med de "vakte« kredse, der fra begyndelsen af 1800-tallet satte sit stærke præg på Salling-Mors egnen, og som videreudviklede sig til en stærk, grundtvigsk bevægelse.

Som ung drog Christen Dalsgaard til København for at modtage undervisning, dels på Kunstakademiet og dels privat. Hans maleriske gennembrud blev et billede af to mormoner, der missionerer $\mathrm{i}$ et hus på landet, fra 1856.

Billedets titel angav Christen Dalsgaard således: »Tvende Mormoner ere paa deres Vandring komne ind i et Tømrehuus paa Landet, hvor de ved Prædiken og ved Fremviisning af nogle af deres Sects Skrifter søge at vinde nye Tilhængere«. 


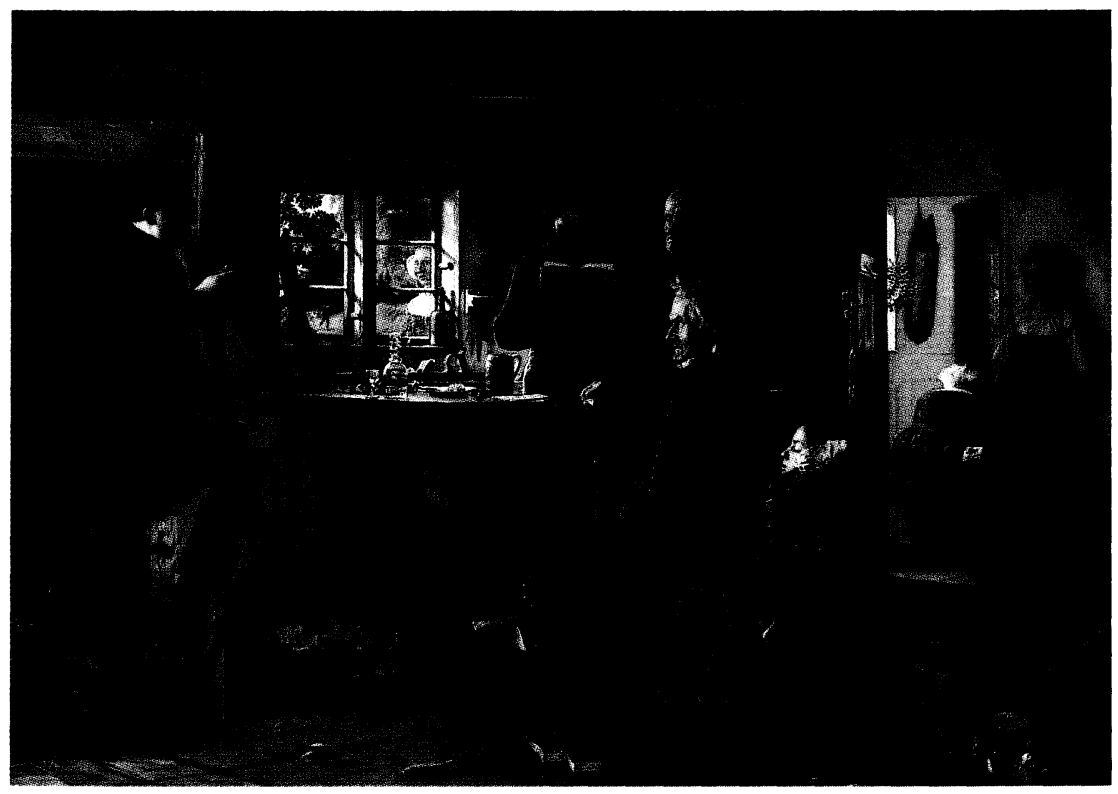

Mormoner på bes $\phi g$ hos en tømrer på landet. 1856.

Olie på larred, 79x110,5 cm. Statens Museum for Kunst 
Fra denne tid kunne Christen Dalsgaard skaffe sig et, om end beskedent, levebrød som genremaler. Christen Dalsgaards genreskildringer drejer sig oftest om dramatiske højdepunkter i almuens tilværelse, gengivet og "sentimentaliseret« ud fra nationalromantiske krav til handling og form.

Motiverne var populære og blev undertiden malet i flere eksemplarer, med små variationer.

Allerede i sine unge år fik Christen Dalsgaard sin første bestilling på religiøs kunst, og da - symptomatisk nok - til Salling-Mors egnen. Til Skive Kirke blev i 1855 bestilt en altertavle med motivet »Engelen, der forkynder Hyrderne Kristi Fødsel« (nu på Skive Museum).

Christen Dalsgaard blev ansat som tegnelærer ved Sorø Akademi i 1862. Han unddrog sig derved - til sine venners bekymring - det kunstnerm̆iljø, han havde tilhørt i København, men ikke mindst økonomiske overvejelser gjorde udslaget til, at han tiltrådte stillingen.

Sorø Akademi indtog på dette tidspunkt en særstilling blandt landets latinskoler, bl.a. var det ejet af universitetet og dermed både rigere og mere veludstyret end de fleste andre af landets latinskoler. Inspireret af stedets mange historiske minder fremsatte Grundtvig sine første højskoletanker med henblik på Sorø Akademi. Der var folk på Sorø Akademi, som var interesseret i Grundtvigs tanker og på deres side værdsat af grundtvigske kredse, bl.a. B.S.Ingemann og C. Hostrup. Den udvirkende og tilskyndende kraft til Christen Dalsgaards ansættelse var D.G.Monrad (1811-1887). Det er i det hele åbenbart at Sorø Akademi for de nationalliberale kredse i København, som både Monrad og andre fra Christen Dalsgaards bekendtskabskreds tilhørte, stod som en skole med en særlig glans.

Christen Dalsgaard levede til sin død i 1906 i Sorø. Enkelte rejser til København og Jylland foretog han $\mathrm{i}$ disse år, men han drog aldrig på større rejser til udlandet.

Tre eksempler på Christen Dalsgaards grundtvigske billedkunst:

\section{Ryslinge Valgmenighedskirke}

Det første væsentlige møde mellem den vækkelsesprægede grundtvigianisme i kirkeligt regi og Christen Dalsgaard er bestillingen af Ryslinge Valgmenigheds altertavle. 


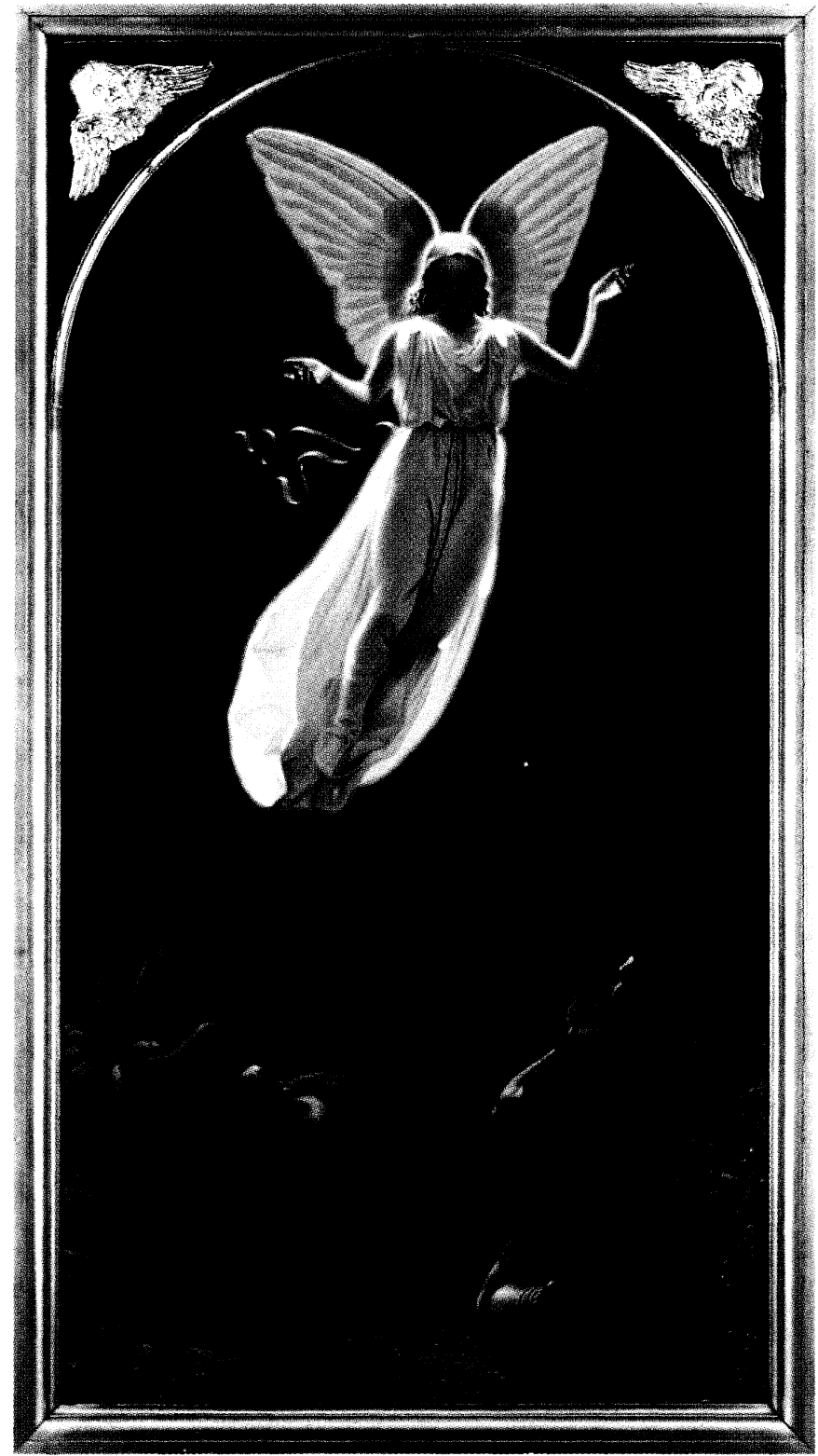

»Englene som forkynder Hyrderne Kristi Fødsel«. 1855. Malet til Skive Kirke, tilhфrer nu Skive Museum. 
Ryslinge valgmenighed er den første valgmenighed i landet, opstået omkring Vilhelm Birkedal. Vilhelm Birkedal (1809-1892) var en af den grundtvigske vækkelsesbevægelses betydeligste præster, og ved skæbnens tilskikkelse blev det ham, der i 1865 dannede den første "frie» menighed i landet. Først efter at loven om valgmenigheder under folkekirken var blevet vedtaget i 1868 , blev hans kirke »legaliseret «. Han havde med sin «frie» menighed vundet et ry som grundtvigianismens førende stridsmand.

Ved Birkedals oprettelse af den fri menighed ved Ryslinge træder Christen Dalsgaards kirkelige kunst for første gang ind i billedet $i$ forbindelse med grundtvigianismen, ganske simpelt fordi der skal skabes en fysisk ramme om menighedens gøremål. Nazarethkirken i Ryslinge blev bygget i 1866, og altertavlen til kirken blev malet i 1869. Motivet var en »uddybelse« af kirkenavnet: »Den hellige Familie i Nazareth«.

Jesus står i midt i billedet i inderlig samtale med Maria, hvis højre hånd peger mod en genstand $\mathrm{i}$ Jesus' venstre hånd. Denne genstand synes at være en døbefont, der så skal ses i sammenhæng med den tempellignende kirkebygning, der i modelstørrelse ses bag Jesus. Josef står i billedets mellemgrund og lytter til Marias og Jesus' samtale. Det landskabelige og arkitektoniske sceneri har et sydlandsk, italiensk præg.

Den hellige familie er fremstillet som en »almindelig " familie, uden glorier el.lign., men den har Guds ord (= Jesus) i sin midte. Altertavlens motiv kan således fungere som et symbol for de midtfynske familier, hvis kristne liv såvel i hjemmet som i menigheden var den fælles basis. Dåbens betydning er understreget ved den døbefont, Jesus holder om, og som han tydeligvis forklarer Maria betydningen af.

Tankegangen i billedet, indholdets »aktuelle« betydning for menigheden, kan også hentes i Grundtvigs digt: »I Nazaret, i trange kår«, bl.a. i følgende strofe:

Da har og Gud et Nazaret

til os etsteds på jorden, en lille køn og yndig plet i syden eller norden, hvor overalt vi ser Guds spor og lytter glade til hans ord som ånd og liv på jorden. (citeret efter Den danske Salmebog) 


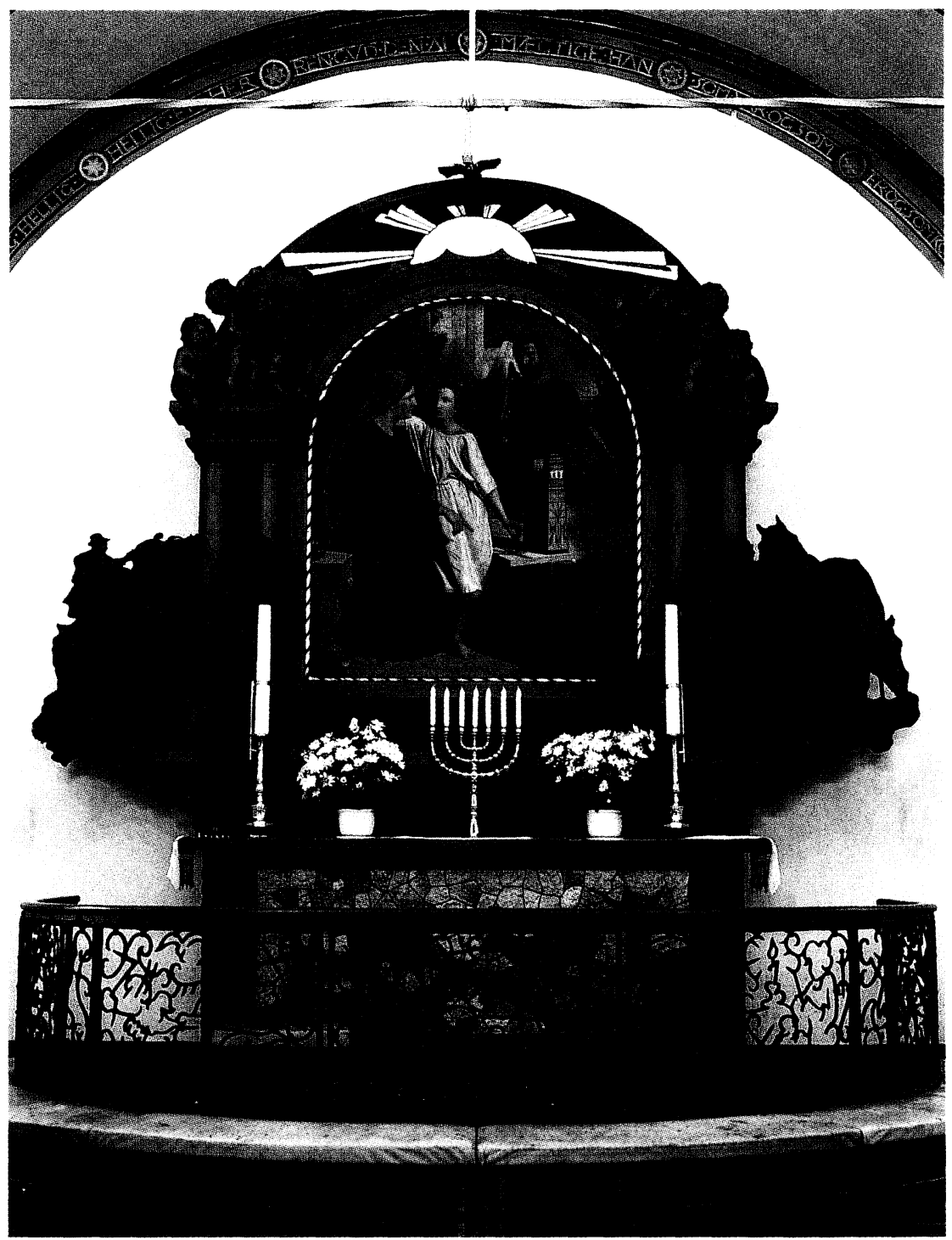

»Den hellige Familie i Nazareth«. 1855.

Malet til Ryslinge Valgmenighedskirke, Fyn.

Foto: H. Bonde Hansen 


\section{Morsø Valgmenighedskirke}

I 1870 påbegyndtes den første valgmenighedskirke i Jylland, i Øster Jølby på Mors. Her havde den grundtvigske vækkelsesbevægelse allerede tidligt slået rod, en friskole og en højskole havde eksisteret fra 1860 'erne, friskolen endog med Christen Kold som lærer i en årrække.

Kirken stod færdig til indvielse i 1871, og den velhavende lægprædikant Peder Larsen Skræppenborg var med ved indvielsen. Det var ved denne lejlighed han besluttede at skænke kirken en altertavle i stedet for det sorte kors, der ved indvielsen udgjorde alterudsmykningen, og som han må have fundet meget »ugrundtvigsk«. Altertavlen i Øster Jølby nævnes utallige steder i den grundtvigske litteratur. Ingen anden altertavle omtales så hyppigt, og det viser noget om dens særstilling.

Der er fyldigere omtale af altertavlens historie i Elise KonstantinHansens bog om »Samliv med dansk kunst « og i bogen om Rasmus Lund, Morsø valgmenigheds første præst. Disse to beretninger synes ikke umiddelbart at stemme overens, men suppleret med oplysninger fra Morsø frimenighedspræst Erik Lau Jørgensen synes begivenhederne at være følgende:

Da Peder Larsen overværede kirkens indvielse den 17. december 1871 og så, at der på altret var anbragt et sort kors, udtalte han omtrent således: "I skal dog heller have en rigtig køn, lys Altertavle, der kan passe til det lyse Syn paa Kristenlivet, Guds Naade har sendt os." Hermed lovede Peder Larsen Skræppenborg at skænke en altertavle til kirken, hvis navn, Ansgarkirken, han var meget begejstret for.

Peder Larsen rejste over til Sorø først på året 1872 for at bestille og drøfte udførelsen af altertavlen med Christen Dalsgaard. Han fortalte kunstneren hvordan han i en drøm havde set billedets motiv, Ansgar døber det første danske barn i Helligbækken ved Hedeby. Dalsgaard var skeptisk og tænkte vel sit om Peder Larsen Skræppenborgs drømmesyn, men han indvilligede $\mathrm{i}$ at forsøge sit bedste med motivet. Der var jo også penge at tjene ved en sådan bestilling, og lønnen som tegnelærer ved Sorø Akademi var ikke fyrstelig.

På hjemvejen fra Grundtvigs begravelse og vennemødet i København i september 1872 drog Peder Larsen inden om Sorø for at hente sin altertavle. Herom beretter Christen Dalsgaards bror, der selv deltog i det grundtvigske liv på Mors:

»Jeg mindes ogsaa, at min Broder har fortalt om Peder Larsens Besøg hos sig, da Billedet med Ramme var bleven færdig og nu skulle 


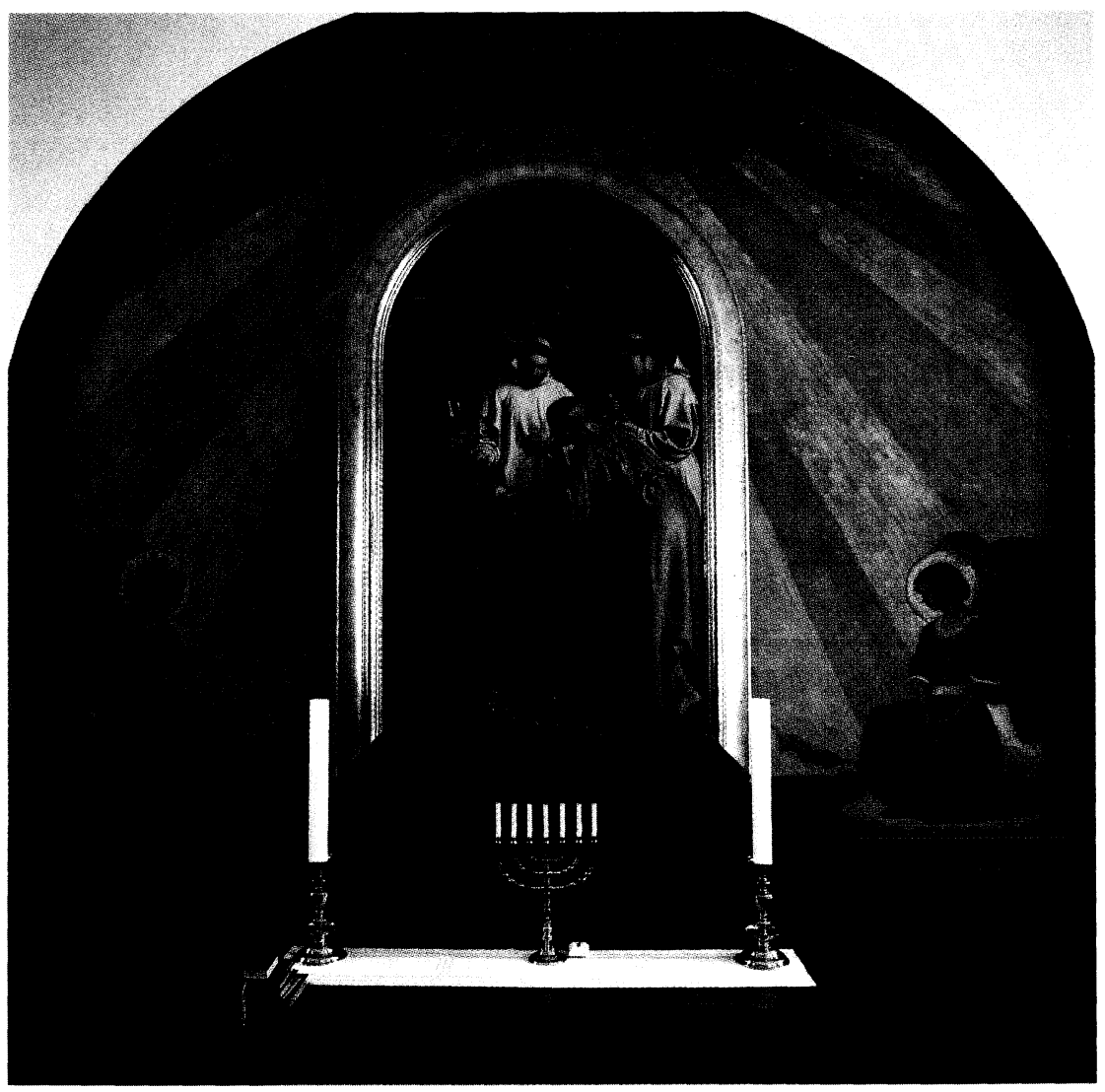

Ansgar dфber et barn. 1872.

Altertavle i Mors $\varnothing$ Frimenighedskirke, Øster Jølby på Mors.

Foto: Kirsten Klein 
afleveres. Da min Broder førte ham ind i Malerstuen og stillede ham overfor Billedet, foldede den gamle Mand Hænderne og hensank i stille Betragtning. Endelig udbrød han:

"Saa takker jeg Vorherre«, men tilføjede saa lidt efter: »Og ogsaa Dem, Dalsgaard!« Disse Ord glædede min Broder, da han deri saa det bedste Vidnesbyrd for, at han havde naaet, hvad han vilde, at frembringe et tiltalende Billede, der, uden at være knyttet til de sædvanlige traditionelle bibelske Motiver, havde en Frihed, og jeg kan sige Finhed over sig, som gør det til det bedste af hans historiske Billeder."

Peder Larsen Skræppenborg nåede ikke selv op til Mors at aflevere altertavlen. Han blev det efterår meget syg og døde i januar 1873. En avlskarl transporterede billedet fra Dons ved Kolding, hvor Skræppenborg boede, til Mors, og altertavlen blev indviet søndagen før jul 1872.

Altertavlen, der stadig befinder sig på sin oprindelige plads i Øster Jølby valg- nu frimenighedskirke på Mors, har altså som motiv en dåbshandling. I forgrunden bøjer en ung mor sit svøbelsesbarn frem mod Ansgar, der øser vand på dets hoved. I baggrunden ses Ansgars ledsa$6+6$ ger, munken Ødbert, der holder et krucifiks i form af et processionskors over barnet.

Sceneriet er henlagt til et skovlandskab, hvorigennem der bugter sig en lille å. Selve dåben forrettes i åen. Vegetationen er frodig, det tætte løvhang og de brede stammer i mellem- og baggrund giver kompositionen en lukket karakter, som en kirke. I mellemgrunden til venstre ses en kvinde, der ledsager en ældre mand henimod den forreste gruppe.

Kompositionen er opdelt $i$ to dele, hvor den nederste del er en "menneskelig« sfære, og den øverste del er en »himmelsk « sfære, med halvbuens krucifiks.

Billedet er således opbygget med en adskillelse af det verdslige og det sakrale, på en formel/symbolsk måde, som kendes fra ikke mindst renæssancens religiøse fremstillinger.

Centrum i billedet er det lille dåbsbarn, klædt i rødt. De tre personer i forgrunden ser alle på det lille barn, der stirrer intenst op mod krucifikset. Vores, beskuerens, indgang til billedet sker ikke mindst ved kvindeskikkelsen i mellemgrunden, hvis udstrakte arm peger ind mod de centrifugale kompositionsmønstre, som blikke og arme i forgrundsfigurerne tilsammen danner. Når beskueren når centrum, barnet, følger man barnets blik op mod korset. Vandringen ind i billedet er både fysisk/kompositionelt og indholdsmæssigt/symbolsk ført til ende. 


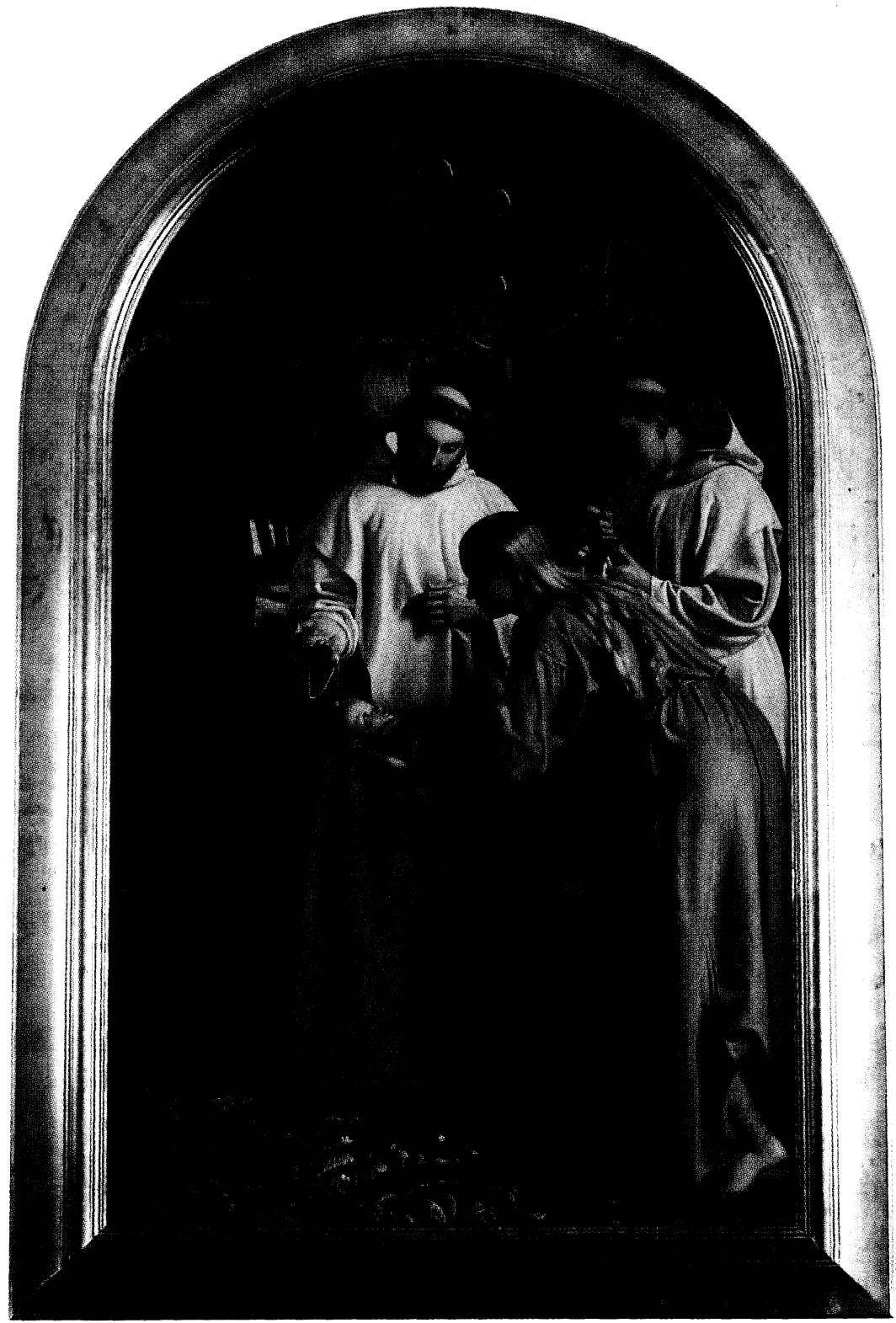

Det lille dåbsbarn, klaedt i rødt, kigger op på krucifikset, som Ødbert holder over dåbshandlingen.

Foto: Kirsten Klein 
Christen Dalsgaards billede er udført i en naturalistisk stil, der virker som en fortsættelse af C.W.Eckersbergs kirkemaleri. Men ud over den, efter min mening, smukke komposition og farveholdning kommer sidst, men ikke mindst det fremstillede indhold.

Personerne er præget af ro, de er hverken skildret dramatisk eller i affekt. Deres fremtoning er enkel, afdæmpet - og derfor desto mere inderligt koncentreret. Genrepræget staffage er undgået, både i klædedragt og omgivelser. Det guddommelige er til stede i billedet via krucifiks-symbolikken.

Er denne altertavle da grundtvigsk, således som man kunne forvente ved en af de første billedkunstneriske opgaver, bestemt til en grundtvigsk valgmenighed? Ja, jeg synes der kan fremhæves mange og vægtige argumenter herfor, primært gennem motivvalget. Stilistisk var billedet traditionelt, - et nybrud i den kunstneriske form kom først senere, med Joakim Skovgaard, og det vakte stor opmærksomhed. Men indholdsmæssigt var altertavlen en dristighed, der i sin konsekvens viste sig mere "grundtvigsk" end altertavlen i Ryslinge.

For det første forener motivet kristendom, folkelighed og historie på en for dansk kirkeudsmykning vistnok hidtil uhørt måde. Der er her sket en sammenkobling af det danske folks historie og kristengørelse.

For det andet fremstilles dåben som det centrale motiv, modsat f.eks. korsfæstelsen eller opstandelsen. I litteraturen om Grundtvigs menighedssyn understreges det hvordan Grundtvig lagde størst betydning i de to sakramenter "ved badet og bordet «, fordi fortid og nutid smelter sammen i Kristi nærvær ved dåb og nadver. Christen Dalsgaards dåbsbillede og det nedenforstående alterbord danner jo en helhed.

For det tredje rummer billedet ud over den på en gang historiske og symbolske fortælling IKKE en morallære eller løftet pegefinger. Den maner ikke til syndsbevidsthed eller sortsyn, men den søger at styrke det menighedsfællesskab, som udfolder sig netop her og som hviler på dansk historie og dansk kristendom.

Endvidere kan det fremhæves i forbindelse med Ansgarkirkens navn og altertavlens motiv, at netop Ansgar - som historisk skikkelse - forener de to »livskredse« i grundtvigianismen, der på den ene side omfatter kristendommen og det religiøse, på den anden side det folkelige og det historisk- nationale. Ansgars missionsværk er for grundtvigianerne den mest skelsættende begivenhed i Danmarkshistorien, idet Danmarks nuværende plads som den sjette af de syv menigheder, som skildret af Grundtvig i »Syvstjernen«, har medført en sammenføjning af 
den mytologisk-historiske arv OG kristendommen. I "grundtvigsk terminologi« blev Ansgar en dansk Jesus-skikkelse, idet han tilførte hedningenationen dens kristne bevidsthed og dermed blev symbolet på DEN DANSKE KRISTENDOM.

\section{Vallekilde Folkehøjskole}

Den karismatiske teolog, feltpræst og lærer Ernst Trier (1837-1893) grundlagde i 1865 Vallekilde Højskole i Nordvestsjælland. Ernst Trier havde fået en solid borgerlig og kristen opvækst i det bedre københavnsk borgerskab, med vægt på og kærlighed til kulturel og kunstnerisk virksomhed, - en kærlighed han bevarede hele livet.

Ernst Trier inddrog billedkunsten i skolens virksomhed så snart, eller næsten før han havde råd til det, ved at lade skolen udsmykke både ude og inde $\mathrm{i}$ årenes løb, - her var tale om en banebrydende indsats.

I midten af 1870 'erne skulle skolen udvides med en større foredragssal, og i den anledning ønskede Trier at bestille en gentagelse af altertavlen i Øster Jølby hos Christen Dalsgaard. En række brevuddrag $i$ forbindelse med denne bestilling er gengivet og kommenteret af Ernst Triers efterfølger som forstander, Povl Hansen, i elevskriftet »Fra Vallekilde Folkehøjskole« fra 1907, og derfor kan vi følge billedets historie trin for trin.

Ernst Trier henvendte sig for første gang skriftligt til Christen Dalsgaard i maj 1876, hvor den nye skolebygning med foredragssalen endnu var under opførelse. Han skriver, hvorledes han kunne tænke sig to kopier af kendte billeder, dels det omtalte af Dalsgaard, og dels et af Wilhelm Marstrand over "Lignelsen om den rige mands gæstebud «.

Trier håbede at kunne få salen færdig til efteråret og ville gerne have, at inventaret i form af loftsbjælker, paneler, bænke m.m. i "stuen « skulle indrettes så det passede med de to billeder. Hertil ville han gerne have Christen Dalsgaards hjælp og bad ham derfor om at komme og se stedet an så hurtigt som muligt. I brevet fra maj 1876 fremfører Ernst Trier begrundelsen for Christen Dalsgaards særstilling blandt samtidens kunstnere:

»De er én af de få kunstnere, til hvis smag jeg har tillid, fordi De ikke vil have kunsten til forlystelse, og De er én af de ganske fă kunstnere, der har sans for det fremblomstrende folkeliv mellem vor ungdom; 


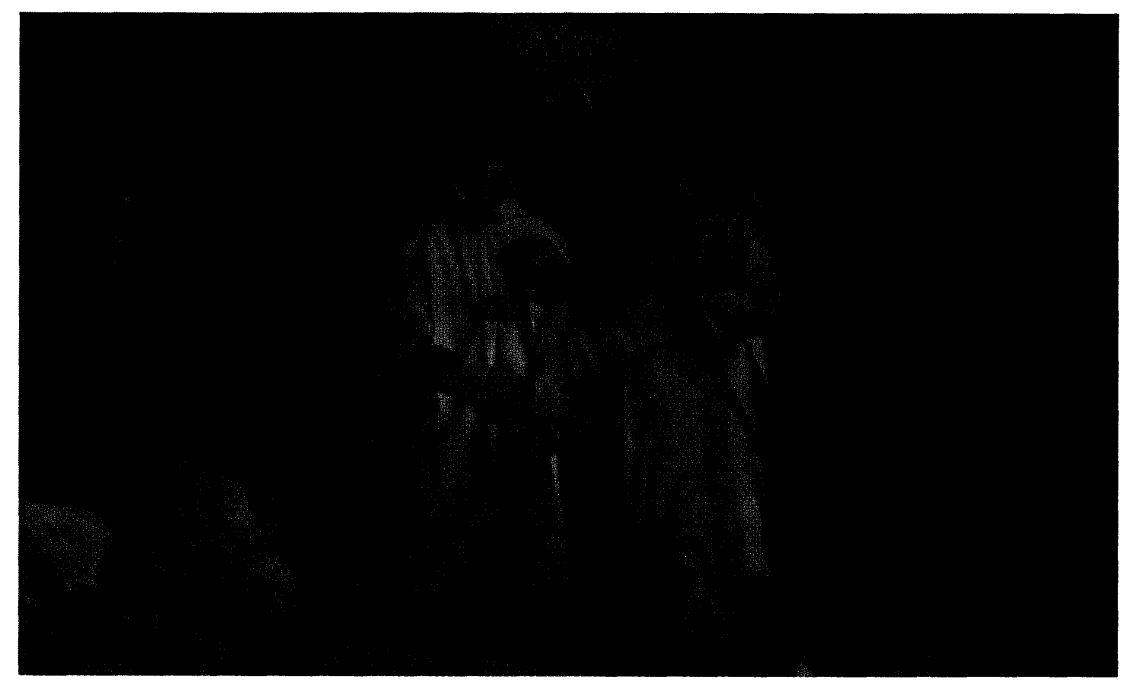

Ansgar dфber et barn. 1878. Udfфrt til Vallekilde Folkehфjskoles foredragssal, Nordvestsjaelland.

Foto: Freddy Sebastian 
og lidt kender jeg dog personlig til Dem - tag mig det nu ikke ilde op, at jeg så frit skriver til Dem om alt dette, og at jeg beder Dem hjælpe mig til at få en smukt udsmykket skolesal!«

Med pastor Glahn, Ernst Triers og Christen Dalsgaards fælles ven i Sorø, som tilskyndende mellemmand aflagde Christen Dalsgaard da i begyndelsen af juni 1876 Vallekilde et besøg og bistod med gode råd til salens udsmykning, hovedsageligt igennem Andreas Bentsen, der var såvel lærer som bygmester på Vallekilde.

Samtidig begyndte tidligere elever at besvare en af Ernst Trier udsendt indbydelse til pekuniært at understøtte forhavendet. I begyndelsen af september kan Trier skrive til Christen Dalsgaard, at indsamlingen går godt, hvorfor arbejdet med Ansgar-billedet kan påbegyndes.

Povl Hansen kommenterer Ernst Triers ønske om en kopi af netop dette billede: »Når billedet $\mathrm{i}$ »Ansgarkirken « på Mors tiltalte Trier så stærkt, så var det ganske sikkert, ikke alene fordi det er et betydeligt kunstværk; men også fordi emnet syntes ham så PASSENDE til at fremstilles i hans ny foredragssal; det var jo mødet mellem det danske folk og Guds menighed, mellem det folkelige og det kristelige, altså netop det, han gærne vilde, skulde opleves af ungdommen på hans skole.«

Udførelsen af Marstrands billede var udelukket af økonomiske grunde, men Dalsgaard påbegyndte sit billede i april 1877. Året efter var det færdigt, og den 19. marts skriver han til Ernst Trier, at han har anmeldt det til forårsudstillingen (på Charlottenborg). Christen Dalsgaard gengiver den for ham så typiske, meget lange og grundige katalog-anmeldelse: »Ansgar og Ødbert døber en ung moder og hendes lille barn $i$ en kilde ved den af dem opførte skole. Flere tilskuere er til stede og bliver på forskellige måder påvirkede af denne handling. Den gamle kriger til venstre - hvem datteren og dattersønnen vil overtale til også at lade sig døbe - standser dog betænkelig i det afgørende øjeblik."

Billedet blev efter udstillingen i København anbragt på sin dertil bestemte plads. Christen Dalsgaard sørgede endvidere for, at en enkel listeramme blev opsat omkring maleriet, men et senere af ham selv tilsendt forslag til en mere kostbar indramning blev ikke realiseret. Han besøgte - trods opfordring hertil - aldrig senere Vallekilde, og han så således ikke maleriet $i$ dets endelige omgivelser (en senere ombygning har medført at billedet ikke længere hænger på sin oprindelige plads).

Billedet er i forhold til altertavlen i Øster Jølby blevet noget omarbejdet. Midtergruppen er den samme, om end dåbsbarnet nu er 
nøgent. Billedets format er ændret, således at det er blevet væsentligt bredere, og til venstre er motivet blevet udbygget med den omtalte skolebygning, en træbygning, fra hvis åbne »veranda" små barnehoveder kigger frem. Denne motiviske udvidelse behøver ingen nærmere begrundelse, når bestemmelsesstedet for billedet tages i betragtning.

Således blev Ansgar-motivet, som Christen Dalsgaards bror hellere betegnede som historisk end religiøst, anvendt som et kristeligt og folkeligt opvækkelsessymbol, og det styrkede Christen Dalsgaards position som foretrukken kunstner blandt Grundtvig-folket i de følgende år.

\section{Afslutning}

Christen Dalsgaard modtog en række andre grundtvigianske bestillingsopgaver, bl.a. kan nævnes Gråbrødre Hospitalskirke i Odense, Vejstrup Valgmenighedskirke og Sønder Næraa Valgmenighedskirke. Produktionen af altertavler ebbede ud i løbet af $1880^{\prime}$ erne, og der blev til gengæld tid til at sysle med bibelske motiver i mindre format.

I Christen Dalsgaards personlige udtalelser, som de fremgår af breve til kollegerne Constantin Hansen og Julius Exner, er der ingen religiøse betragtninger, men mange oplysninger om de billeder, han udfører og påtænker, såvel genrebilleder som bibelske motiver.

På opfordring af kunsthistorikeren Julius Lange skrev Christen Dalsgaard i 1865 mere udførligt om sig selv, - men gav dog også tydeligt udtryk for sit ubehag ved at gøre det. I sin levnedsskildring til Julius Lange skriver han $\mathrm{i}$ forbindelse med året $1855 \mathrm{og}$ sin første altertavle, til Skive Kirke - omtalt ovenfor, - at: »Det blev ikke udstillet, noget jeg idethele nødigt gjør ved mine Altarbilleder.«

Christen Dalsgaard adskilte således i omtalen af sig selv og i den diskretion, han udviste over for kolleger og kunsthistorikere, sit virke som kunstner i to halvdele: Den officielle kunstnerkarriere bestod af genremalerier, som blev udstillet og dermed underlagt offentlig bedømmelse.

Som kunstner for altertavler og bibelske opgaver til privatpersoner holdt Christen Dalsgaard oplysningerne om sine bestillinger tættere ind til kroppen, og han udstillede dem sjældent. At dette blev gjort helt bevidst illustreres af ovenstående udtalelse. 


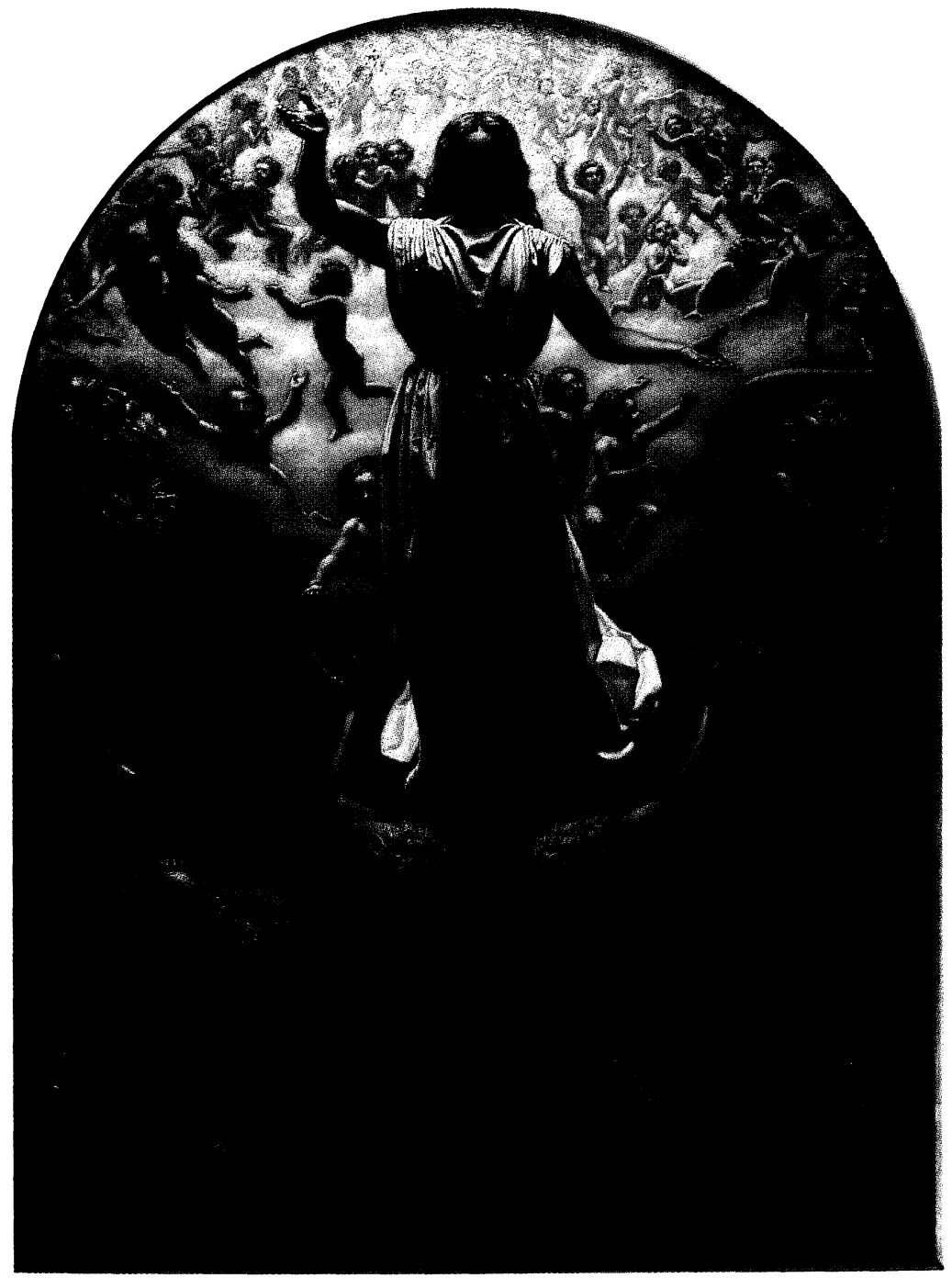

Christen Dalsgaard malede 21 »Smaa bibelske Billeder « fra midten af 1880'erne og frem til 1902, hvor de blev udstillet samlet på Charlottenborg. Billederne tilhфrer $i$ dag Vestsjallands Kunstmuseum i Sor $\phi$. Dette er nr. 3, »Hyrdernes Englesyn«, hvorefter Christen Dalsgaard i kataloget citerer Luk. 2.

Foto: Bent Ryberg 
I grundtvigske kredse har Christen Dalsgaards religiøse malerier udgjort et specifikt motivgrundlag, der i en indforstået terminologi har bekræftet menighedens fællesskab og det fælles værdigrundlag. Julius Lange udtalte at Christen Dalsgaard især mestrede det psykologiske udtryk, i skildringen af menneskers sjæleliv og samvær. Det var en opfattelse, som Joakim Skovgaard og mange andre i samtiden delte. I kunsthistorisk perspektiv synes denne bedømmelse retfærdig nok, om end Dalsgaards kunst altid har forekommet nogle for fersk. Men inden for grundtvigske kredse blev denne vurdering ophøjet til en unison besværgelse, og begejstringen for Dalsgaards kunst fandt sin begrundelse i, at hans billeder var så sjæleligt gribende. Det indebar også at han inden for det grundtvigske fællesskab blev opfattet som den kunstner, der forstærkede og fornyede motivernes »menneskelige« indhold. En stilistisk fornyelse var der ikke tale om hos Christen Dalsgaard, hvis detaljerede og omhyggelige arbejdsmåde $i$ al væsentlighed forblev uændret. Den nye tids form og stil brød frem med næste generations billedkunstnere, hvor frem for alle Joakim Skovgaard vakte såvel forfærdelse som begejstring. Men det er en anden historie!

\section{Note}

Denne artikel bygger på undersøgelser, der blev foretaget i forbindelse med mine specialestudier i 1977-78. Specielt interesserede læsere er velkomne til at kontakte mig for yderligere kommentarer, korrektioner og nye oplysninger. 


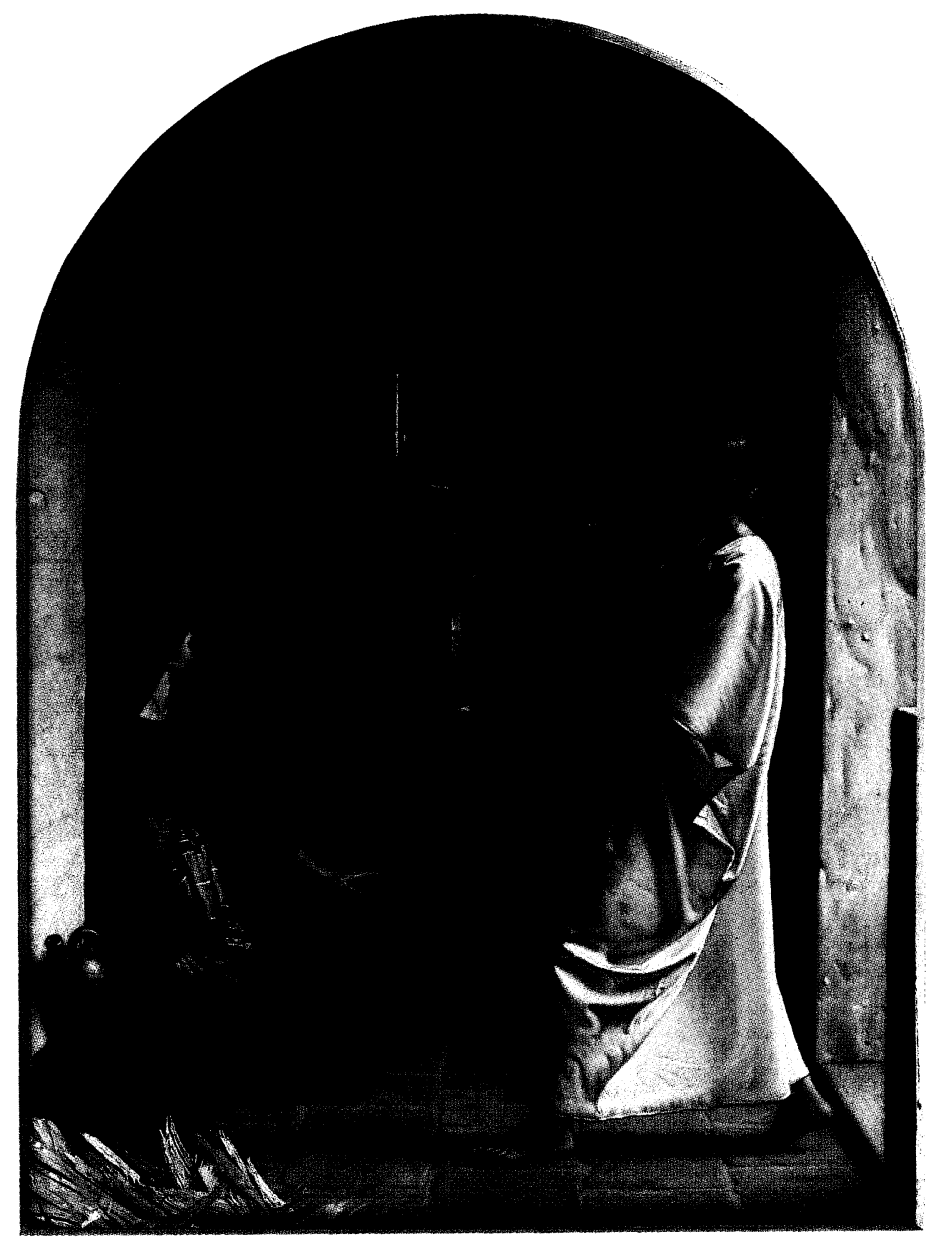

»Jesus under Opvaksten $i$ Nazareth. Og han var dem undergiven «. Dette er $n r .7$ i serien af »Smaa bibelske Billeder «. Christen Dalsgaard skrev til Julius Lange, at - efter at have lart at beherske formen - ... »strabte jeg isar efter at faa mine Figurer levende, og at fremstille deres Sjaleliv med Kraft og Klarhed; det syntes og synes mig endnu at vare det Hovedsagentlige i Kunsten, hvis noget for resten kan siges at vare det."

Vestsjallands Kunstmuseum i Sorø.

Foto: Bent Ryberg 